\title{
SYK Gene
}

National Cancer Institute

\section{Source}

National Cancer Institute. SYK Gene. NCI Thesaurus. Code C26536.

This gene plays a role in receptor tyrosine phosphorylation signal transduction, phagocytosis, endothelial cell growth and proliferation. 